\section{Canopy Cover and Root-zone Heating Effects on Fall- and Spring-grown Leaf Lettuce Yield in Ohio}

\author{
Natalie R. Bumgarner ${ }^{1}$, Mark A. Bennett ${ }^{2}$, Peter P. Ling ${ }^{3}$, \\ Robert W. Mullen ${ }^{4}$, and Matthew D. Kleinhenz ${ }^{1,5}$
}

AdDitionAL INDEX wORDs. low tunnel, high tunnel, season extension, microclimate modification, Lactuca sativa

SUMMARY. Low and high tunnels and root-zone heating systems are proven tools in horticultural production. However, impacts of their separate and combined application on crop yield, composition, and microclimates are underreported. We addressed these gaps in the literature by exposing lettuce (Lactuca sativa) to four microclimates established with low and high tunnels and root-zone heating during the spring and fall of 2 years in Wooster, $\mathrm{OH}$. Red-leaved romaine lettuce cultivars Outredgeous and Flagship were direct-seeded into raised beds in both outdoor and high-tunnel settings in early October and late March and harvested multiple times over 4 weeks. Half of all plots in each setting were underlain by electric heating cables, and half were covered with 0.8 -mil, clear, vented, low tunnels. A growing medium consisting of peat moss, compost, soil, and red clover (Trifolium pratense) hay was used, and all plots were overhead-irrigated. Soil and air temperatures were monitored throughout the experiments, which were repeated four times ( 2 seasons/ year $\times 2$ years). Here, we report primarily on treatment effects on crop yield and related variables. Root- and shoot-zone conditions and cultivar significantly affected leaf biomass in both settings (outdoor, high tunnel), while population was more often affected in the outdoor experiments. Microclimate main effects were more prevalent than cultivar effects or interactions. Leaf yield was greater in lowtunnel-covered and bottom-heated plots than in uncovered and unheated plots. We take these data as further evidence of the potential to alter lettuce yield through root- and shoot-zone microclimate modification, particularly in regions prone to dynamic seasonal and within-season temperature and light conditions. The data also suggest that the relative performance of low and high tunnels in the production of short-statured, quick-cycling crops during fall and spring be more thoroughly evaluated.

$\mathrm{M}$ anaging the microclimate immediately surrounding plants and products - composed of temperature, light, humidity, and other conditions - is fundamental to horticultural production, postharvest handling, and research. Microclimate management often involves the use of plastics,

Salaries and research support provided in part by State and Federal funds appropriated to the Ohio Agricultural Research and Development Center, The Ohio State University. Work also supported in part by grants from the Ohio Vegetable and Small Fruit Research and Development Program. Use of trade names does not imply endorsement of the products named nor criticism of similar ones not named.

The critical reading of the manuscript by Joe Scheerens and material support by AT Films and Shamrock Seeds is gratefully acknowledged.

${ }^{1}$ Horticulture and Crop Science, The Ohio State University-OARDC, Wooster, OH 44691

${ }^{2}$ Horticulture and Crop Science, The Ohio State University, Columbus, $\mathrm{OH} 43210$

${ }^{3}$ Food, Agricultural, and Biological Engineering, The Ohio State University-OARDC, Wooster, OH 44691

${ }^{4}$ Environmental and Natural Resources, The Ohio State University-OARDC, Wooster, OH 44691

${ }^{5}$ Corresponding author. E-mail: kleinhenz.1@osu.edu. for example, increasingly deployed as the cover of low and high tunnels (Lamont, 2005; Wells and Loy, 1985, 1993; Wittwer and Castilla, 1995). Low- and high-tunnel use are popular because they can raise farm productivity and profit potential through direct and indirect effects on crops and crop management (Carey et al., 2009; Lamont, 2005; Waterer, 2003; Wells and Loy, 1993). Low and high tunnels tend to reduce crop stress and often increase yield relative to the uncovered condition. Low and high tunnels differ in size and scope of application but share operational principles of heat and humidity retention, shading and light dispersion, and wind mitigation, especially of aerial environments.

Active root-zone or floor heating is common in year-round greenhouse systems (Elwell et al., 1985; Sachs et al., 1992; Shedlosky and White, 1987; Wai and Newman, 1992) but less common in low- and high-tunnel systems. In greenhouse systems, rootzone heating is thought to maintain or improve ornamental and vegetable plant growth and quality and lower aerial heating costs (Janes and McAvoy, 1983; Sachs et al., 1992; Shedlosky and White, 1987; Trudel and Gosselin, 1982). Relative to shoot-zone heating and regardless of setting, root-zone heating may also alter broad aspects of crop physiology including root growth, growth regulator production, transport and/or activity, water and nutrient uptake, and photosynthate allocation (Bowen, 1991; Cooper, 1973; Li et al., 1994; Macduff, 1989). As in greenhouse systems, integrating root- and shoot-zone heating in low- and hightunnel systems may create microclimates that promote specific relationships between primary and secondary metabolism that influence yield, quality, profitability, and sustainability.

Unlike in many greenhouses, temperature modification in low and high tunnels is often a comparatively crude, localized, passive, and sunlightdependent process unaccompanied by supplemental lighting (Nair and Ngouajio, 2010; Soltani et al., 1995; Waterer, 2003; Wells and Loy, 1985, 1993 ). Active heating within high tunnels, if used at all, typically is applied intermittently to elevate shoot-zone temperatures, especially for low-temperature protection (Lamont, 2005; Lamont

\begin{tabular}{lllc}
\hline $\begin{array}{l}\text { Units } \\
\begin{array}{l}\text { To convert U.S. to SI, } \\
\text { multiply by }\end{array}\end{array}$ & U.S. unit & SI unit & $\begin{array}{l}\text { To convert SI to U.S., } \\
\text { multiply by }\end{array}$ \\
\hline 29.5735 & $\mathrm{fl} \mathrm{oz}$ & $\mathrm{mL}$ & 0.0338 \\
0.3048 & $\mathrm{ft}$ & $\mathrm{m}$ & 3.2808 \\
0.0929 & $\mathrm{ft}^{2}$ & $\mathrm{~m}^{2}$ & 10.7639 \\
0.0283 & $\mathrm{ft}^{3}$ & $\mathrm{~m}^{3}$ & 35.3147 \\
3.7854 & $\mathrm{gal}$ & $\mathrm{L}$ & 0.2642 \\
2.54 & inch(es) & $\mathrm{cm}$ & 0.3937 \\
0.0254 & $\mathrm{mil}$ & $\mathrm{mm}$ & 39.3701 \\
28.3495 & $\mathrm{oz}$ & $\mathrm{g}$ & 0.0353 \\
93.0102 & $\mathrm{oz} / \mathrm{ft}$ & $\mathrm{g} \cdot \mathrm{m}^{-1}$ & 0.0108 \\
305.1517 & $\mathrm{oz} / \mathrm{ft}^{2}$ & $\mathrm{~g} \cdot \mathrm{m}^{-2}$ & 0.0033 \\
$\left({ }^{\circ} \mathrm{F}-32\right) \div 1.8$ & ${ }^{\circ} \mathrm{F}$ & ${ }^{\circ} \mathrm{C}$ & $\left(1.8 \times{ }^{\circ} \mathrm{C}\right)+32$
\end{tabular}

Horflechnology · December $201121(6)$ 
et al., 2003). Moreover, low and high tunnels are routinely deployed in areas characterized by dynamic within- and across-season fluctuations in sunlight and temperature levels. Therefore, it is reasonable to suspect that greenhouse studies, especially those featuring root-zone heating, may have yielded an understanding of temperature effects upon which low- and high-tunnel users cannot rely exclusively, particularly if their system involves a short-statured, quick-cycling crop grown during fall and spring seasons. We set out to strengthen the record of temperature effects in low- and high-tunnel systems by employing low tunnels, a high tunnel, and root-zone-heating cables (alone and in combination) and multipronged data collection during springand fall-time production of leaf lettuce in 2008-10.

\section{Materials and methods}

SITE AND EXPERIMENTAL GROWING SYSTEM. Two experiments were conducted at the Horticulture and Crop Science Department Farm of the Ohio Agricultural Research and Development Center (OARDC) in Wooster, $\mathrm{OH}$. The experiments were conducted simultaneously and followed duplicate methodological approaches. The experiments differed only in the setting in which they were completed: one experiment was conducted in a high tunnel, and the second was conducted outdoors in an adjacent open field. Both experiments were repeated in two spring and fall seasons in 2008-10.

Both experiments employed a split-plot design containing four replications per treatment. Treatments represented eight combinations of four microclimates and two cultivars also functioning as main and subplot factors. Eight wood-framed raised beds $(2 \mathrm{ft} \times 8 \mathrm{ft} \times 6$ inches $)$ contained the four main plot microclimates: 1) control (no low tunnel or subsurface heating), 2) subsurface-heated with heating cable, 3 ) aerial-covered with low tunnel, and 4) subsurface-heated and aerial-covered. Within these main plots were four randomized subplots $(2 \times 2 \mathrm{ft})$ containing the two lettuce cultivars. Each of the eight microclimate $\times$ cultivar treatments was replicated four times in each experiment for a total of 32 subplots. The Fall 2008, experiments tested only 'Outredgeous' lettuce in the four microclimates, while all subsequent experiments tested two lettuce cultivars as subplot treatments. Also, in Fall 2008, a $13 \times 40 \times 6-\mathrm{ft}$ single-layer 6-mil plastic tunnel was used, while all subsequent high-tunnel experiments were carried out in a $30 \times$ $80 \times 13$-ft single-bay, gothic style, single-layer 6-mil clear polyethylenecovered high tunnel.

A woven black weed barrier (Hummert International, Earth City, $\mathrm{MO}$ ) was placed under all raised beds and covered with a 1 to 1.5 -inch layer of sand (Woodland Mulch, Kidron, $\mathrm{OH})$. A second layer of weed barrier $(3 \times 9 \mathrm{ft})$ was stapled to the raised bed frame to contain the medium. The growing medium consisted of $(\mathrm{v} / \mathrm{v})$ $35 \%$ peat (Premier Horticulture, Quakerstown, PA), 35\% dairy manure compost (OARDC), 15\% shredded organic red clover hay (OARDC), and $15 \%$ silt loam field soil (OARDC). A mixer (model 12193; Bouldin and Lawson, McMinnville, TN) was used to completely blend the materials. Each main plot was filled with $\approx 5.2 \mathrm{ft}^{3}$ of new medium (average $5.8 \mathrm{pH}, 1.1 \%$ nitrogen, $19.0 \%$ carbon) for each experiment. Polystyrene foam dividers (Dow Chemical Co., Midland, MI) separated the subplots within each main plot.

Control plots consisted of unheated raised beds also lacking a lowtunnel cover. Root-zones in treatments 2 and 4 were heated with a $40-\mathrm{ft}$ automatic electric heating cable (WrapOn Co., Bedford Park, IL) under the rooting medium at about 4 -inch depth and triggered to function at medium temperatures below $23{ }^{\circ} \mathrm{C}$. The heating cable was attached to the upper layer of woven weed barrier at 3 -inch spacing to provide even heating and prevent cable contact, and the operation of each cable was governed by a thermostat with its sensing unit in continual contact with the rooting medium at 4 -inch depth. Treatment 3 main plots were covered by a single layer of 0.8 -mil slitted polyethylene (Hummert International) stretched across four wire hoops and attached to the ground with landscape staples to create an $18 \times 30$-inch low tunnel. Treatment 4 main plots were polyethylene-covered and cable-heated as described earlier.

About 1000 preweighed primed and pelleted seeds of the two red leaf romaine lettuce cultivars, Outredgeous (Johnny's Selected Seeds, Winslow, ME) and Flagship (Shamrock Seeds,
Salinas, CA) were sown in seven parallel rows at 3 -inch spacing within each subplot, as recommended for baby leaf lettuce production. Seeds were evenly placed on the substrate and covered by hand on 9 Oct. 2008, 21 Mar. 2009, 10 Oct. 2009, and 15 Mar. 2010. All plots were overhead watered by hand as needed by microclimate treatment, generally twice daily with $\approx 1 \mathrm{~L} /$ subplot of clear water. No additional fertilizer was added.

Environmental data. Air and soil temperatures were recorded continuously at 30-min (Fall 2008, Spring 2009) and 15-min (Fall 2009, Spring 2010 ) intervals in both experiments using data loggers (Hobo ProV2; Onset Computer Co., Bourne, MA). All main plots were equipped with a separate data logger, and sensors were protected with a radiation shield. Air and soil temperatures were recorded 8 inches above and 1 to 1.5 inches below the medium surface, respectively. Data from the monitoring of each main plot replication are summarized in Table 1. Periodic readings of photosynthetically active radiation (LI250-A; LI-COR Biosciences, Lincoln, NE) were also taken at canopy level in each experiment.

Crop Data. Microclimate effects on plant growth and yield were measured at four developmental stages using destructive and nondestructive sampling. Data are presented for two of these stages. Early stand establishment was measured via nondestructive counts of emerged seedlings taken $5 \mathrm{~d}$ after sowing on 10 inches of the center of the third row in each subplot. Plant number and biomass were measured through plant samples collected $\approx 2$ and 3 weeks after sowing (WAS). In this process, all plants were removed intact and by hand from a 10 -inch section of a randomly chosen row (excluding edge rows 1 and 7) in each subplot, placed in a sealed plastic bag, and cooled $\left(5^{\circ} \mathrm{C}\right)$ until weighing. All plants from each subplot sample were counted and weighed in bulk. Thereafter, 10 representative plants were selected from the bulk subplot sample, and their roots and shoots were separated with a razor blade and weighed. Finally, yield was recorded $\approx 4$ WAS (7 Nov. 2008, 22 Apr. 2009, 9 Nov. 2009 , and 14 Apr. 2010) by collecting all above-ground biomass from a standardized $2-\mathrm{ft}^{2}$ section of each subplot. Leaves and stems were placed in plastic 
bags and stored on ice in coolers until being processed within $4 \mathrm{~h}$ of harvest. Germination data were collected on a thermogradient table (model DB2000; Van Dok and De Boer, Enkhuizen, The Netherlands). Petri dishes $(100 \times 15 \mathrm{~mm}$; Fisher Scientific, Waltham, MA) were lined with blotting paper (3.25-inch discs; Anchor Paper Co. St. Paul, MN) and filled with $\approx 40 \mathrm{~mL}$ of the above described medium. Twenty-five primed and pelleted seeds were evenly spread on the surface of the medium and moistened. Germination was tested at 10 discrete temperatures in $2{ }^{\circ} \mathrm{C}$ increments from 10 to $28^{\circ} \mathrm{C}$. A total of 80 petri dishes were placed on the thermogradient table in rows of eight, with each row containing four replications of each cultivar at each temperature. Emerged and viable seedlings were counted and removed from the petri dishes $3,5,7$, and $10 \mathrm{~d}$ after sowing.

Data ANALYsis. The high-tunnel and outdoor experiments were not replicated in space; therefore, data from these experiments were analyzed separately. Data collected at 2 and 4 WAS were also analyzed separately within experiment to uncover potential treatment effects on growth through time. A Proc Univariate procedure was carried out to test for normality on all data. Normally distributed data were analyzed using untransformed data in Proc Mixed. Data with a nonnormal distribution were log-transformed before analysis (SAS version 9.2; SAS Institute, Cary, NC), a common step in the handling of data displaying a skewed distribution. Means were then back-transformed for inclusion in tables. Microclimate and cultivar were analyzed as fixed effects and replications within years were analyzed as random effects in Proc Mixed. Treatment means were separated using a pdiff difference statement at a $P \leq 0.05$ level of significance when microclimate and cultivar fixed effects were significant at $P \leq 0.05$.

\section{Results}

The separate and combined use of low and high tunnels and heating cables established contrasting, characteristic microclimates, as illustrated by air and soil temperature data in Table 1 . These microclimates, in turn, were associated with consistent treatment-based differences in lettuce yield (Tables 2 and 3 ). Yield trends evident at 2 WAS tended to prevail at 4 WAS. And, 
Table 2. Lettuce plant number and shoot fresh weight from destructive samplings of two red romaine lettuce cultivars taken 2 weeks after sowing in four microclimates in outdoor and high-tunnel settings in eight experiments in 2008-10 in Wooster, $\mathrm{OH}$.

\begin{tabular}{|c|c|c|c|c|c|c|c|c|c|}
\hline & \multicolumn{9}{|c|}{ Mean plant count (no./ft of row) and shoot fresh wt $(\mathrm{g} / \mathrm{ft} \text { of row })^{\mathrm{z}}$} \\
\hline & & \multicolumn{2}{|c|}{ Fall 2008} & \multicolumn{2}{|c|}{ Spring 2009} & \multicolumn{2}{|c|}{ Fall 2009} & \multicolumn{2}{|c|}{ Spring 2010} \\
\hline & & 2 -wk count & 2 -wk wt & 2 -wk count & 2 -wk wt & 2 -wk count & 2 -wk wt & 2 -wk count & 2-wk wt \\
\hline \multirow[t]{3}{*}{ Microclimate } & Control & 51 & 3.68 & $65 \mathrm{~b}^{\mathrm{y}}$ & $3.74 \mathrm{a}$ & $72^{x}$ & $2.09 \mathrm{a}$ & 56 & $1.75 \mathrm{a}$ \\
\hline & Subsurface-heated & 56 & 6.07 & $65 \mathrm{~b}$ & $7.33 \mathrm{c}$ & 77 & $4.50 \mathrm{~b}$ & 58 & $2.61 \mathrm{~b}$ \\
\hline & Aerial-covered & 65 & 5.96 & $56 \mathrm{ab}$ & $5.15 \mathrm{~b}$ & 70 & $3.58 \mathrm{~b}$ & 51 & $3.02 \mathrm{~b}$ \\
\hline \multirow[t]{3}{*}{ Cultivar } & Outredgeous & 59 & 5.56 & 63 & 6.41 & 74 & 4.01 & 59 & $3.33 \mathrm{~B}^{\mathrm{y}}$ \\
\hline & Flagship & — $^{\mathrm{w}}$ & $-^{\mathrm{w}}$ & 57 & 5.91 & 70 & 4.37 & 53 & $2.63 \mathrm{~A}$ \\
\hline & \multicolumn{9}{|c|}{ Outdoor } \\
\hline Microclimate & Control & $19 \mathrm{a}$ & $0.15 \mathrm{a}$ & $44 \mathrm{a}$ & $0.52 \mathrm{a}$ & $54 \mathrm{a}$ & $0.56 \mathrm{a}$ & $35 \mathrm{ab}$ & $0.29 \mathrm{a}$ \\
\hline \multirow[t]{2}{*}{ Cultivar } & Outredgeous & 45 & 0.88 & 57 & 1.49 & 61 & 1.61 & 37 & 0.50 \\
\hline & Flagship & ${ }^{\mathrm{w}}$ & $-^{\mathrm{w}}$ & 60 & 1.59 & 65 & 1.91 & 34 & 0.48 \\
\hline
\end{tabular}

${ }^{\mathrm{z}} 1$ plant $/ \mathrm{ft}=3.2808$ plants $/ \mathrm{m}, 1 \mathrm{~g} / \mathrm{ft}=3.2808 \mathrm{~g} \cdot \mathrm{m}^{-1}=0.0353 \mathrm{oz} / \mathrm{ft}$.

${ }^{y}$ Means within columns and microclimates (lowercase letters) or cultivars (uppercase letters) followed by the same letter are not significantly different statement when fixed effects were significant at $P \leq 0.05$

${ }^{x}$ See Table 4 for microclimate $\times$ cultivar interaction means separation.

${ }^{w}$ Fall 2008 experiments compared microclimate treatments without cultivar subplots.

Table 3. Lettuce shoot fresh weight measured 4 weeks after sowing in two red romaine cultivars exposed to four microclimates in outdoor and high-tunnel settings in eight experiments in 2008-10 in Wooster, OH.

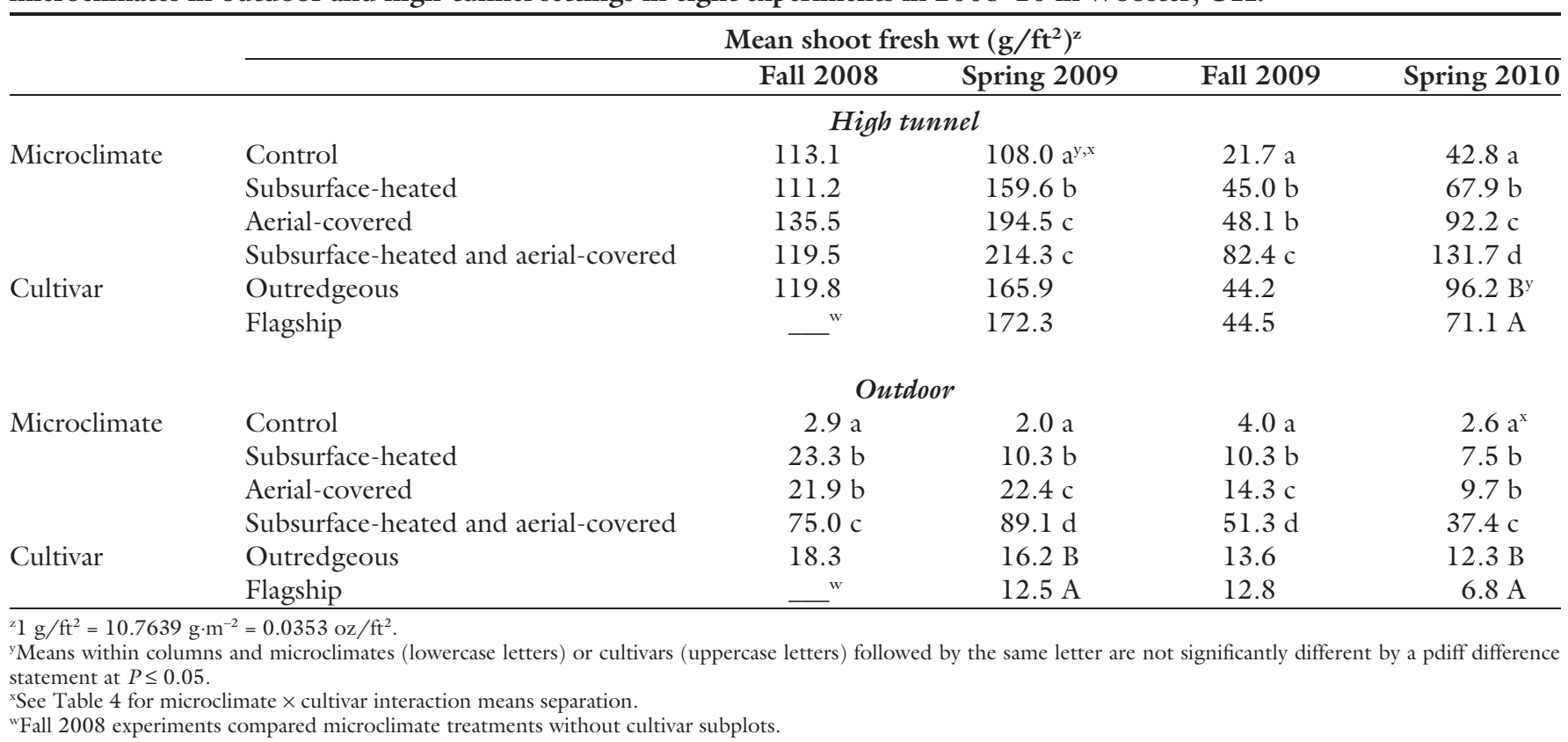

treatment effects on yield were significant in three of the four high tunnel and all four outdoor experiments (Tables 2 and 3 ). Regardless of setting, yield tended to be higher in polyethylenecovered and root-zone cable-heated plots and lower in uncovered, unheated plots. Cultivar significantly affected yield in three experiments with 'Outredgeous' tending to register the greatest yield. However, yield was less consistently and dramatically affected by cultivar as a main effect and interactions involving cultivar than by microclimate treatments. When present, statistically significant interactions involving cultivar appeared to result from cultivar-based differences in plant population and growth, themselves driven in part by unknown genetic factors (Table 4 ). 
Table 4. Microclimate $\times$ cultivar effects on lettuce shoot fresh weight measured 4 weeks after sowing and plant number measured 2 weeks after sowing in two red romaine cultivars exposed to four microclimates in outdoor and high-tunnel settings in three experiments in 2009-10 in Wooster, OH.

\begin{tabular}{|c|c|c|c|c|}
\hline \multirow[b]{3}{*}{ Microclimate } & \multicolumn{4}{|c|}{ Mean shoot fresh wt $\left(\mathrm{g} / \mathrm{ft}^{2}\right)$ and plants $(\text { no. } / \mathrm{ft} \text { of row })^{\mathrm{z}}$} \\
\hline & \multirow[b]{2}{*}{ Cultivar } & Spring 2009 4-wk shoot wt & Fall 2009 2-wk count & \multirow{2}{*}{$\frac{\text { Spring } 20104 \text {-wk shoot wt }}{\text { Outdoor }}$} \\
\hline & & \multicolumn{2}{|c|}{$\begin{array}{c}\text { High tunnel } \\
\end{array}$} & \\
\hline & Flagship & $126.7 \mathrm{~b}$ & $74 \mathrm{ab}$ & $2.2 \mathrm{a}$ \\
\hline \multirow[t]{2}{*}{ Subsurface-heated } & Outredgeous & $158.0 \mathrm{c}$ & $84 \mathrm{~b}$ & $7.0 \mathrm{c}$ \\
\hline & Flagship & $161.1 \mathrm{c}$ & $71 \mathrm{a}$ & $8.1 \mathrm{c}$ \\
\hline \multirow{2}{*}{$\begin{array}{l}\text { Subsurface-heated } \\
\text { and aerial-covered }\end{array}$} & Outredgeous & $221.7 \mathrm{~d}$ & $74 \mathrm{ab}$ & $55.9 \mathrm{e}$ \\
\hline & Flagship & $207.0 \mathrm{~d}$ & $64 \mathrm{a}$ & $25.0 \mathrm{~d}$ \\
\hline
\end{tabular}

${ }^{\mathrm{z}} \mathrm{l} \mathrm{g} / \mathrm{ft}^{2}=10.7639 \mathrm{~g} \cdot \mathrm{m}^{-2}=0.0353 \mathrm{oz} / \mathrm{ft}^{2} ; \mathrm{l}$ plant $/ \mathrm{ft}=3.2808$ plants $/ \mathrm{m}$.

${ }^{y}$ Microclimate $\times$ cultivar interaction means within columns followed by the same letter are not significantly different at $P \leq 0.05$.

\section{Microclimate effects on plant biomass}

High-tunnel EXPERIMENTS. Yield in the high-tunnel setting was influenced by microclimate treatment in three of four experiments, the lone exception being Fall 2008 (Table 3). Interestingly, plant population recorded 2 WAS was unaffected by microclimate in Fall 2009 and Spring 2010 (Table 2) although treatment effects on biomass production were typically evident at the same and later harvest in 2009 and 2010 (Tables 2 and 3). Yield in the high-tunnel setting was clearly influenced by microclimate and typically lowest in uncovered and unheated plots. The relative impacts of root, shoot, and root- and shoot-zone heating on yield also varied by year, season, and crop stage. Still, the data clearly indicate most trends established by 2 WAS tended to hold at 4 WAS. Overall, these results indicate that a slitted polyethylene cover established at sowing, whether alone or in combination with root-zone heating, often resulted in the greatest biomass production.

OUTDOOR EXPERIMENTS. Biomass production in the outdoor setting was influenced by microclimate treatment in all four experiments (Table 3) but, perhaps, in a manner more mitigated by plant population than in the high-tunnel setting. Plant populations recorded 2 WAS were lowest in uncovered, unheated control plots in three of four experiments; only the rank order and significance of treatment effects on plant population varied slightly by year and season (Table 2 ). Yield recorded 2 and 4 WAS displayed a similar trend (lowest in the control, variable rank order among the root and shoot alone heated treatments).
However, as in the high-tunnel setting, root- and shoot-zone heating tended to result in the greatest yield. Interestingly, the relative impacts of root- and shoot-zone heating when practiced alone varied slightly among year, season, and crop stage. Still, the use of a slitted polyethylene covering alone resulted in statistically higher yield values than using rootzone heating alone in two of four experiments.

\section{Cultivar effects on plant biomass}

High-TUNNEL EXPERIMENTS. Cultivar main effects on biomass production were significant only in Spring 2010 when 'Outredgeous' out-yielded 'Flagship' 2 and 4 WAS (Tables 2 and $3)$. A significant microclimate $\times$ cultivar interaction was detected for shoot fresh weight 4 WAS in Spring 2009 and plant population 2 WAS in Fall 2009 (Table 4).

OUTDOOR EXPERIMENTS. As in the high-tunnel experiments, cultivar main effects on yield were less common than microclimate effects in the outdoor setting. 'Outredgeous' was greater than 'Flagship' yield 4 WAS in Spring 2009 and Spring 2010 (Table $3)$. A significant microclimate $\times$ cultivar interaction was detected only at 4 WAS in Spring 2010 (Table 4).

\section{Discussion}

We set out to document the impacts of root- and shoot-zone heating in low- and high-tunnel production on leaf lettuce yield, a dynamic with scientific and practical consequences. The results suggest that microclimates created by this experimental system profoundly affected leaf yield as measured 2 and 4 WAS, regardless of setting (outdoor, high tunnel). Specifically, the results suggest that a lack of aerial cover and supplemental root-zone heating tends to significantly suppress biomass production relative to all other microclimates; that the presence of both a cover and a supplemental subheating can enhance yield, most consistently under outdoor conditions; and that the distinction between aerial cover and root-zone heating in terms of yield potential may be minor in some seasons and settings. The data also suggest that these microclimate effects on yield may begin with differential stand establishment in some settings.

\section{Interactive and main effects of microclimate and cultivar on plant population}

In this study, the hand sowing of primed and pelleted seeds into an organic medium was used collectively to minimize the potential impact of adverse environmental conditions on stand establishment as outlined previously (Cantliffe, 1989). As hoped, stand differences were less common than microclimate differences. Still, plant populations recorded 2 WAS varied among microclimates in all four outdoor experiments but in only one high-tunnel experiment (Table 2). Plant populations did not vary significantly with cultivar 2 WAS in either experimental settings (high tunnel, outdoor). However, cultivar-specific germination temperature optima may partially explain the significant interactive effect of cultivar and microclimate on plant population and yield data obtained in two high-tunnel experiments (Table 4). In the Spring 2009 high-tunnel experiment, yield of 'Flagship' was higher than of 'Outredgeous' in the 
control, but not in the other three microclimates. Similarly, in Fall 2009, 'Flagship' populations were significantly lower than 'Outredgeous' in some heated root-zone microclimates. Thermogradient table germination tests were then completed to help explain these trends in these two high-tunnel experiments (Fig. 1). In this controlled setting, 'Flagship' germination exceeded 'Outredgeous' germination at lower temperatures while the reverse was observed at higher temperatures. These cultivar-specific germination impacts may have contributed to microclimate $\times$ cultivar interactions in those two experiments.

High-TunNel experiments. Plant populations were affected by microclimate in only one of four hightunnel experiments [Spring 2009 (Table 3)]. Plant populations were generally similar among microclimates, suggesting that conditions supported stand establishment and that differences in yield followed growth. These outcomes are supported by previous work suggesting that high-tunnel-field soil temperature differentials may exceed air temperature differentials during some seasons (Both et al., 2007; Knewtson et al., 2010). If true, stand establishment of direct-seeded lettuce could be promoted in high-tunnel systems during periods when low external temperatures would suppress it regardless of whether other strategies are applied.

OUTDOOR EXPERIMENTS. Microclimate treatment, more than cultivar, clearly influenced plant populations recorded 2 WAS in all four outdoor experiments (Table 2). Treatment rank order differences tended to hold across experiments: covering, heating, or covering and heating raised beds generally resulted in greater populations compared to the control as would be suggested by germination data collected in a controlled environment (Fig. 1) but over the temperature range recorded during these experiments (Table 1 ). However, microclimate effects on population tended to be less consistent than microclimate effects on yield.

\section{Microclimate effects on plant biomass}

Biomass production is a function of plant population and growth. In this study encompassing a range of stand establishment-growth conditions, biomass production appeared to hinge primarily on growth, our major interest, and less on plant population. Leaf and stem tissue mass also appeared to respond primarily to microclimate treatment more so than to cultivar. Experiments involving microclimate and cultivar treatments were repeated in multiple years, seasons, and settings. Although differences between hightunnel and outdoor settings and seasonal variation were of secondary interest and largely untestable in this study, further experimentation should investigate their role.

Microclimate effects on yield were similar in the outdoor and high-tunnel experiments in most years. Control, aerial covered or subheated, and covered and heated plots tended to display

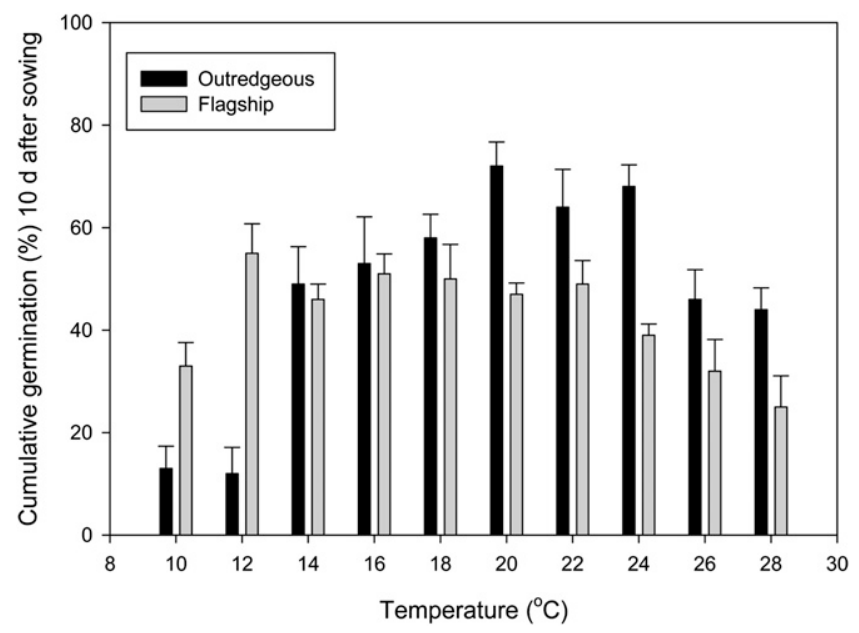

Fig. 1. Cumulative germination (mean \pm SE) of 'Outredgeous' and 'Flagship' red romaine lettuce $10 \mathrm{~d}$ after sowing in an organic medium on a thermogradient table with 10 temperature treatments $\left(10-28^{\circ} \mathrm{C}\right)$. Data include emerged and viable seedlings $(n=4) ;\left(1.8 \times{ }^{\circ} \mathrm{C}\right)+32={ }^{\circ} \mathrm{F}$. the lowest, intermediate, and highest levels of biomass production, respectively. Only the magnitude of the variation within settings and experiments varied. In the outdoor setting, biomass production in aerial covered and subheated plots was greater than in all other plots in all experiments. Microclimate effects were more closely associated with microclimate experiment combinations in the high tunnel, suggesting that the relatively more buffered high-tunnel environment diminished some treatment effects when external conditions were closer to optimal for growth. Taken together, the outcomes of the outdoor and hightunnel experiments suggest that the cost-benefit relations of investments in low- vs. high-tunnel growing systems for short-statured, quick-cycling crops such as baby lettuce are worthy of further focused investigation.

High-tunnel experiments. High-tunnel systems are noted for their ability to shield crops against abiotic and biotic stress, especially when a second, interior layer of plastic is used near the crop, as in this study (Lamont, 2005; Lamont et al., 2003). Here, significant differences among four interior microclimates were noted in three of four experiments, Fall 2008 the exception. Air and soil temperature averages were highest in Fall 2008 (Table 1), suggesting that the constant heating capacity of the three treatments was unnecessary or detrimental to optimize growth in that experiment. The warmer high-tunnel environment with potentially lower air volume and circulation was also conducive to plant disease, an additional potential drag on biomass production.

Plant health was sometimes a factor in the high-tunnel experiments but less so in the outdoor experiments. Fungal disease, primarily Rhizoctonia, was occasionally noted in aerial and subheated plots within the high tunnel, an outcome reported as likely when air movement is reduced, higher temperatures prevail, and free moisture is consistently abundant in the roothypocotyl zone (Grosch and Kofoet, 2003). Electric heating cables surrounded by a high organic matter rooting medium covered with a dense canopy required a consistently high level of soil moisture to be maintained, a condition favoring disease. Upon disease identification, ventilation was increased, and in the Fall 2009 and 
Spring 2010 experiments, etridiazole with thiophanate-methyl (Banrot 40\% wettable powder; Scotts, Marysville, $\mathrm{OH}$ ) was applied to limit disease progression. Variations in root-zoneheating method, more frequent ventilation, a rooting medium lower in organic matter, and/or other tactics may limit this weakness of our experimental system when applied elsewhere.

OUTDOOR EXPERIMENTS. Microclimate modification resulted in greater yields, relative to control plots, in all outdoor experiments. Installing plastic covers over horticultural crops is known to increase growth and yield in multiple systems and crops (Nair and Ngouajio, 2010; Rekika et al., 2009; Soltani et al., 1995; Wells and Loy, 1985). However, this approach relies exclusively on passive solar and soil warming. The influence of air- or water-mediated active root-zone heating is most often studied in growth chambers or greenhouses (Economakis, 1997; Elwell et al., 1985; Li et al., 1994; Shedlosky and White, 1987). Fewer recent studies (Bumgarner et al., 2012; Hunter et al., 2010) have capitalized on earlier reports (e.g., Cameron Brown and Gray, 1957; Canham, 1952; Rykbost et al., 1975) and considered the impacts of direct soil heating in differently engineered low- and high-tunnel systems, especially in temperate climates.

The experimental system used here permitted direct comparisons of three microclimates and a control group in outdoor and high-tunnel settings. Outdoors, aerial-covered and subheated plots produced up to 40 times more above-ground biomass than control or other experimental plots. Covering raised beds or heating the root-zone they contain separately also increased yield relative to no action but to lesser extents than combining the two steps. Data reported here suggest that the on-farm value of covering or subheating alone or in combination be examined thoroughly and that such tests account for potential shifts in irrigation and/or disease management that the strategies may involve. Relative to no intervention, covering and subheating appear to be required to maximize fall and spring outdoor, raised bed baby lettuce yield in most years under the experimental conditions experienced here.

Seasonal environmental conditions unquestionably alter the impact of crop management techniques. However, unlike in the high-tunnel experiments, spring and fall seasonal yield averages tended to be similar in outdoor experiments. Interestingly, the average air and soil temperatures for the two lowest yielding outdoor experiments were similar to those recorded for the two higher yielding experiments (Table 3 ). This observation corroborates earlier assertions that temperature effects on crop growth and tissue composition vary both with the crop stage at which certain temperatures are experienced and the mean temperature of the entire study period (Bumgarner et al., 2012; Gazula et al., 2005; Kleinhenz and Wszelaki, 2003; Radovich et al., 2005). Direct-seeded, quick-cycling crops such as baby lettuce may respond strongly to dynamic environments involving rapid and potentially extreme temperature and light fluctuations over narrow timeframes influencing germination and growth. Growers and scientists accept the challenge of identifying microclimate management techniques that are adaptable and consistently effective and economical. Here, we provide further evidence that rootand shoot-zone microclimate modification can enhance lettuce biomass production, especially when used simultaneously in outdoor growing systems.

\section{Literature cited}

Both, A.J., E. Reiss, J.F. Sudal, K.E. Holmstrom, C.A. Wyenandt, W.L. Kline, and S.A. Garrison. 2007. Evaluation of a manual energy curtain for tomato production in high tunnels. HortTechnology 17:467-472.

Bowen, G.D. 1991. Soil temperature, root growth, and plant function, p. 309329. In: Y. Waisel, A. Eshel, and U. Kafkafi (eds.). Plant roots: The hidden half. Marcel Dekker, New York.

Bumgarner, N.R., J.C. Scheerens, R.W. Mullen, M.A. Bennett, P.P. Ling, and M.D. Kleinhenz. 2012. Root-zone temperature and nitrogen affect the yield and secondary metabolite concentration of fall- and spring-grown, high-density leaf lettuce. J. Sci. Food Agr. 92:116-124.

Cameron Brown, C.A. and A.W. Gray. 1957. Electricity in modern commercial horticulture. Proc. Inst. Electrical Electronics Eng. 104:249-257.

Canham, A.E. 1952. Electrical soil warming for salad crops in frames. Brit. Electrical Allied Ind. Res. Assn. Tech. Rpt. W/T24.

Cantliffe, D.J. 1989. Stand establishment. Acta Hort. 247:175-179.
Carey, E.E., L. Jett, W.J. Lamont, T.T. Nennich, M.D. Orzolek, and K.A. Williams. 2009. Horticultural crop production in high tunnels in the United States: A snapshot. HortTechnology 19: 37-43.

Cooper, A.J. 1973. Root temperature and plant growth. Commonwealth Agr. Bureaux. Farnham Royal, England.

Economakis, C.D. 1997. Effect of rootzone temperature on growth and water uptake by lettuce plants in solution culture. Acta Hort. 449:199-203.

Elwell, D.L., M.Y. Hamdy, W.L. Roller, A.E. Ahmed, H.N. Shapiro, J.J. Parker, and S.E. Johnson. 1985. Soil heating using subsurface pipes: A decade of research results at OSU/OARDC. Ohio Agr. Res. Dev. Ctr. Res. Bul. 1175.

Gazula, A., M.D. Kleinhenz, J.G. Streeter, and A.R. Miller. 2005. Temperature and cultivar effects on anthocyanin and chlorophyll b concentrations in three related Lollo Rosso lettuce cultivars. HortScience 40:1731-1733.

Grosch, R. and A. Kofoet. 2003. Influence of temperature, $\mathrm{pH}$ and inoculum density on bottom rot on lettuce caused by Rhizonctonia solani. J. Plant Dis. Prot. 110:366-378.

Hunter, B., D. Drost, and B. Black. 2010. High tunnel lettuce in Utah. Utah State Ext. Publ. Horticulture/ HighTunnels/ 2010-04pr.

Janes, H.W. and R. McAvoy. 1983. Deleterious effects of cool air temperature reversed by root-zone warming in poinsettia. HortScience 18:363-364.

Kleinhenz, M.D. and A. Wszelaki. 2003. Yield and relationships among head traits in cabbage as influenced by planting date and cultivar. I. Fresh market. HortScience 38:1349-1354.

Knewtson, S.J.B., E.E. Carey, and M.B. Kirkham. 2010. Management practices of growers using high tunnels in the central great plains of the United States. HortTechnology 20:639-645.

Lamont, W.J. 2005. Plastics: Modifying the microclimate for the production of vegetable crops. HortTechnology 15:477-481.

Lamont, W.J., M.D. Orzolek, E.J. Holcomb, K. Demchak, E. Burkhart, L. White, and B. Dye. 2003. Production system for horticultural crops grown in the Penn State high tunnel. HortTechnology 13:358-362.

Li, X., Y. Feng, and L. Boersma. 1994. Partition of photosynthates between shoot and root in spring wheat (Triticum aestivum L.) as a function of soil water 


\section{Research Reports}

potential and root temperature. Plant Soil 164:43-50.

Macduff, J.H. 1989. Growth and nutrient uptake in response to root temperature. Asp. Appl. Biol. 22:23-32.

Nair, A. and M. Ngouajio. 2010. Integrating rowcovers and soil amendments for organic cucumber production: Implications on crop growth, yield, and microclimate. HortScience 45:566-574.

Radovich, T.J.K., M.D. Kleinhenz, J.G. Streeter, R. Miller, and J.C. Scheerens. 2005. Planting date affects total glucosinolate concentrations in six commercial cabbage cultivars. HortScience 40:106110.

Rekika, D., K.A. Stewart, G. Boivin, and S. Jenni. 2009. Row covers reduce insect populations and damage and improve early season crisphead lettuce production. Intl. J. Veg. Sci. 15:71-82.
Rykbost, K.A., L. Boersma, H.J. Mack, and W.E. Schmisseur. 1975. Yield response to soil warming: Vegetable crops. Agron. J. 67:738-743.

Sachs, R.M., I. Sisto, B.M. Jenkins, and G.W. Forister. 1992. Plant response and energy savings for bench-top-heated greenhouses. Sci. Hort. 49:135-146.

Shedlosky, M.E. and J.W. White. 1987. Growth of bedding plants in response to root-zone heating and night temperature regimes. J. Amer. Soc. Hort. Sci. 112:290-295.

Soltani, N., J.L. Anderson, and A.R. Hamson. 1995. Growth analysis of watermelon plants grown with mulches and rowcovers. J. Amer. Soc. Hort. Sci. 120:1001-1009.

Trudel, M.J. and A. Gosselin. 1982. Influence of soil temperature in greenhouse tomato production. HortScience 17:928929.

Wai, K.S. and S.E. Newman. 1992. Air and root-zone temperatures influence growth and flowering of snapdragons. HortScience 27:796-798.

Waterer, D. 2003. Yield and economics of high tunnels for production of warmseason vegetable crops. Hort Technology 13:339-343.

Wells, O.S. and J.B. Loy. 1985. Intensive vegetable production with row covers. HortScience 20:822-826.

Wells, O.S. and J.B. Loy. 1993. Rowcovers and high tunnels enhance crop production in the northeastern United States. Hort Technology 3:92-95.

Wittwer, S.H. and N. Castilla. 1995. Protected cultivation of horticultural crops worldwide. HortTechnology 5:6-23. 